\title{
A Gap Model Analysis of Laboratory Service Quality at Engineering Faculty of Private University
}

\author{
${ }^{1}$ NUGRAHA, ${ }^{2}$ DEWI SHOFI, ${ }^{3}$ IYAN BACHTIAR, ${ }^{4}$ KAMAL IMRAN MOHD SHARIF \\ 123 Universitas Islam Bandung, Jl. Tamansari No. 1, Indonesia \\ 4 Universiti Utara Malaysia, Kedah Darul Aman, Malaysia \\ correspondence author: nugraha692016@gmail.com
}

\begin{abstract}
The gap between students and laboratory managers at the faculty of engineering is a problem discussed in this study. This study aims to discover the gap between laboratory managers at the engineering faculty and customer perspectives (students) in the importance of service and performance satisfaction. Service Quality (SERVQUAL) method is used in this study to determine the value of perceptions and expectations of students as customers. The results of the research show that the average values of the dimensions of service quality (tangible, empathy, responsiveness, reliability, assurance) as a whole are 4.679 for the average of expected value and 3.913 for the average of perceived value. It means there are still gaps since the average of expected value is greater than the actual value. Thus, it can be concluded that the perceived value of the overall quality dimension is lower than the expected value, meaning the students are not satisfied because their expectations have not fulfilled yet and there are gaps between students and laboratory managers in the engineering faculty. Laboratory managers are advised to improve service that has a large gap, namely tangible, by providing comfortable, clean, and spacious laboratory rooms in accordance with laboratory standards; complete and adequate supporting facilities for practicum; and the quality and quantity of practicum tools in accordance with the needs of the practicum process.
\end{abstract}

Keywords: gap model analysis, quality of service, laboratory

\section{Introduction}

A laboratory is a place for students to conduct education and teaching, training, and research aims at developing theories that have been obtained earlier in the class. Research group of lecturers can also use the laboratory for their research activity in addition to their educational and teaching obligations and community service. This research group is not only lecturers but can also involve students. Students who join such a research group will have an improvement in his/her ability to analyze, work, and think scientifically; and research of lecturers will also increase and be of high quality. Improvement of laboratories, especially at engineering faculty, needs to be developed so that it can provide good services and satisfy the students who do practical work. Besides that, lecturers will also be more productive in researching with their research groups.
The Faculty of Engineering, founded in 1973, in its development has now three undergraduate study programs (S1). Three undergraduate study programs (S1) at the Faculty of Engineering are Urban and Regional Planning Engineering (planology engineering), industrial engineering study program, mining engineering, one professional program that is the engineer profession study program (PSPPI), and postgraduate study program (S2 ) of master of urban planning. The focus of this research is twelve laboratories in the S1 program that have various practicum where one laboratory organizes more than one practicum. Details of the laboratories in the engineering faculties include (a) the urban planning study program has four laboratories including PPSR laboratories (spatial system planning and design), mapping laboratories, studio laboratories, as well as energy and environmental laboratories; (b) the

Received: 2020-03-28, Revised: 2020-05-05, Accepted: 2020-06-03. 
NUGRAHA. et al. A Gap Model Analysis of Laboratory Service Quality at Engineering Faculty ...

mining engineering study program has four laboratories including mine laboratories, geological laboratories, exploration laboratories, and mine planning and simulation laboratories; (c) the industrial engineering study program has four laboratories including production systems laboratory, management of quality laboratory, a decision information system laboratory, and an analysis of work design and ergonomics laboratories.

Higher education improves the quality of an individual's life (Afridi et al., 2016). Outputs from higher education are human resources that will play a role in development and industry. Meanwhile, the users of higher education are various parties, including students, parents of students, and corporates that employ graduates from an educational institution. Students are direct users of an educational service system because they are directly involved in the process carried out by an educational institution. Thus, higher education should provide satisfactory services to students to make them believe they are in the right place that indeed provides educational services; the right place that supports and develops student's potential to be ready in facing competition in the world of work (Yulianti, 2017).

Education is an institution that has significantly shifted to the knowledge economy. The market of higher education institutions has caused students to increasingly care about their position as customers. Higher education has become a global business and universities/colleges must continue to look for options to provide the best higher educational services (Mohamad Yusof et al., 2012).To gathered information to improve her teaching skills and develop her ability to communicate (Ahmadi, Dadi. \& Yanuarti, 2020)

Although there is competition in research and innovation, universities are also expected to provide high-quality services. Therefore, the assessment of service quality in higher institutions can provide important contributions and inputs useful for the management and staff to continuously improve the quality of education (Al-Alak \& Alnaser, 2012).

The SERVQUAL method has been widely applied by researchers in higher education to assess customer perceptions of service quality (Khodayari \& Khodayari, 2011; Mohamad Yusof et al., 2012; Al-Alak \& Alnaser, 2012; Amelia, Hidayanto, \& Hapsari, 2011).
A literature review has shown that many studies used the SERVQUAL instrument to measure service quality in higher education. Legčević (2009) studied students' expectations and perceptions of service quality at the faculty of law of Osijek University in Croatia and found that students' expectations exceeded their perceptions.

Zeshan, Afridi and Khan (2010) assessed service quality of eight business schools in Pakistan and found out that the students perceived low quality in all five dimensions of service quality (tangible, empathy, responsiveness, reliability, assurance) in all institutions. Abu Hasan, Abd Rahman, and Abd Razak (2008) studied service quality at private institutions of higher education and discovered that all five dimensions and service quality as a whole have a significant relationship. Student satisfaction and empathy have the strongest relationship followed by assurance, physical evidence, responsiveness, and reliability.

Khodayari and Khodayari (2011) studied perception and expectation at Azad Islamic University in Iran with the result that there was a gap between students' expectations and perceptions among dimensions of service quality. It means reliability, tangibles, responsiveness, assurance, and empathy are crucial for students. Furthermore, the branch of the Islamic University Azad Firoozkooh should allocate more funds to improve its performance.

Mohamad Yusof et al. (2012) who studied the quality of service in higher education between research universities and non-research universities found that the tangible dimension is the most important, while empathy and assurance are the least important. The results of the study help academics and administrators allocate their resources according to their needs.

Al-Alak and Alnaser (2012) examined the relationship between dimensions of service quality (tangible, empathy, responsiveness, reliability, assurance) and overall service quality with the satisfaction of undergraduate students at the Faculty of Business at the University of Jordan. Their research findings indicate that the dimensions of assurance and reliability of service quality are the two most important dimensions associated with improvement.

Amelia et al. (2011) reported that the SI/IT service quality at STMIK (school of 
informatics and computer management) MDP Palembang in Indonesia had a gap between expectations and service performance. The highest gap is in the reliability dimension and the lowest is in the assurance. Therefore, improving the quality of STMIK MDP services is directed at increasing user satisfaction.

Yousapronpaiboon (2014) in the results of his research revealed that in the analysis of the gap between service perceptions and expectations, all scores for perceptions are lower than expectations. This shows that many efforts are needed to improve the quality of service. Educational institutions need to improve facilities and equipment to reduce the gap between the perceptions and expectations of undergraduate students and help higher education in Thailand as well.

The problem to be discussed in this study is student complaints or gaps in service quality that have not been satisfactorily provided by laboratories in the faculty of engineering. This study has a purpose to identify the gaps between laboratory managers in the Faculty of Engineering and student perspectives on the importance of service and performance satisfaction. The Service Quality (SERVQUAL) method is used in this study through 5 service quality gaps, namely 1 ) the knowledge gap, 2) the standard gap, 3) the delivery gap, 4) the communication gap, and 5) the service gap.

To get a competitive advantage, many business institutions, especially in the service industry, concentrate on quality (McColl et al., 1998). Good and superior service quality affects consumers' strong desire to buy back (Taylor \& Baker, 1994). The idea is that good and superior service quality will ultimately be transformed into financial perceptions that will lead to improvement and profit for the institution (Jumus \& Koleoglu, 2002; Zeithaml, 2000; in Hoe, 2004). Thus, the success of sustainable competition will be created because institutions that are ready to provide quality services will eventually develop an image and reputation that is very difficult to follow and emulate by competitors (Rapert \& Wren, 1998). The level of importance of the quality of academic services of a university or college with the respondents of a student, lecturer, and employee is an important variable in this dimension so that it is necessary to determine the factors that shape the quality of academic services in university or college (Nugraha et al., 2015). The most appropriate strategy in enhancing the quality of academic services in higher institutions is to improve the existing variables on service quality as evidenced by the suitability in the field, including the suitability of the curriculum between expectations and reality, the suitability of lecture infrastructure between expectations and reality, the suitability of lecture implementation between expectations and reality, and the suitability of academic guidance between expectations and reality (Amin., 2017).

This research applies standard SERVQUAL questionnaire (expectations, perceptions) to collect data. The quality of education services is measured by a 5 -item Likert scale ranging from strongly agree to strongly disagree. Comparisons are made between the current quality of education service scores (perceptions) and student scores regarding the desired quality (expectations) to measure the quality gaps. Positive scores indicate the services provided exceed student expectations; negative scores indicate current education services do not meet student expectations and are an indication of quality gaps. A zero score indicates there is no quality gap, implying that service quality is at the level expected by students (Alijanzadeh et al., 2018). Service quality is defined as the difference between performance/perception and expectation of items that represent specific areas of performance for services. Service quality is an important factor for service institutions in positioning themselves strongly in a competitive environment (Gagandeep Banga et al., 2013).

According to Fitzsimmons \& Mona (2011), The quality of service is something complex. Guests or customers will assess service quality (servqual) through the five principles of service dimensions as a measure, namely Tangible, Empathy, Reliability, Responsiveness, and Assurance, better known by the abbreviation of TERRA. Tangibles (measurable evidence) describe physical facilities, equipment, and appearance of personnel and the presence of users. Empathy includes a sense of caring and individual attention to users. Responsiveness is the willingness to help customers and provide convenient attention. Reliability refers to the expertise or ability to provide the promised service reliably and accurately. Assurance is an employee who is polite and knowledgeable or has the extensive insight to provide trust and confidence to customers.

Service quality or better known as 
Servqual is a service quality measurement model that was originally conceived and introduced by Zeithaml, Parasuraman, and Berry in Gaspersz (2012). This model is also known as the Gap Analysis which is closely related to the consumer satisfaction model based on the disconfirmation approach. The gap analysis model is also related to the consumer satisfaction model based on the performance attributes that increase greater than the expectations of the attributes concerned; then the perception or performance on service quality will have a positive impact or vice versa (Tjiptono \& Chandra, 2011). Parasuraman, Zeithaml, and Berry in Tjiptono dan Chandra (2011) described in detail the five service quality gaps that can be a source of problems in service quality. A model called service quality was developed with the aim of helping the managers to analyze and assess the source of quality problems and understand ways to improve service quality. In addition, service quality is used as a tool or instrument to diagnose the achievement of service quality based on a conceptual model of service quality that conceived and introduced by Parasuraman et al. (1985). The service quality (servqual) model has also been developed and built by Parasuraman et al. (1988) to measure service quality. According to Parasuraman et al. (1988), service quality is the ability and expertise of institutions in meeting or overcoming consumer expectations, where consumer expectations are defined as the interests or desires of consumers. In this regard, the quality of services provided greatly influences customer satisfaction from institutions, organizations, or companies. According to (Tjiptono \& Chandra, 2011) there are some gaps that can fail the delivery of service to consumers.
The service quality (servqual) method was pioneered and developed by Parasuraman (Zeithaml et al, 2008) and consists of expectations and perceptions. Expectations contain questions to confirm the general expectations of consumers of service quality. Performance or perception contains questions to find out and measure the performance or perception of consumers to institutions or companies with certain categories. The service quality model shown in figure 1 is developed with the aim of helping the decision-makers (managers) to understand, analyze, and assess the source of service quality problems and find ways to overcome those problems. Educational policies, students" background (social and economy) and how important the subjects for the future are part of aspects should be understood to support the good learning (Ahmadi, Dadi \& Yanuarti, 2020).

The horizontal dashed line as shown in figure one separates two main things: the top part shows phenomena related to customers and the bottom part refers to phenomena relating to institutions, organizations, companies, or service providers. The top part relating to customers is influenced by gethok tular (word of mouth) communication, customer's personal needs, past experience, and expected services which are strongly influenced by the marketing communication activities of the institution/organization. Whereas, the lower part of the picture, namely perceived customer service, is the result of a series of decision making and activities or internal institutions. Management's perceptions or performance of customer expectations will produce and guide decisions regarding quality or service specifications that must be followed by institutions/organizations and applied in service delivery to customers.

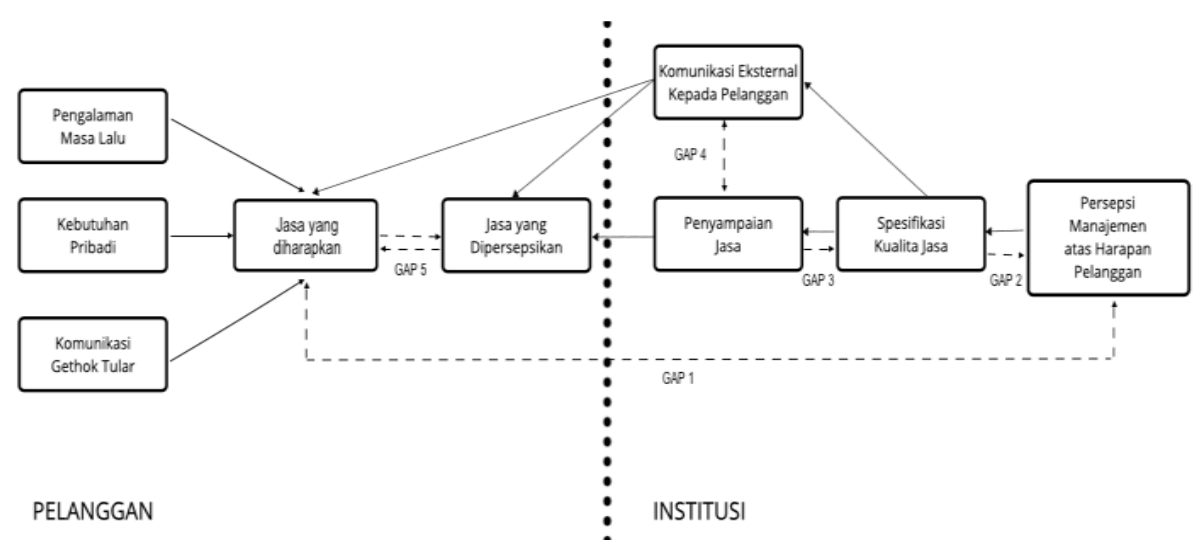

Figure 1. Conceptual Model of Service Quality (SERVQUAL) 
Customers who experience the production process and delivery of service quality as a component of process-related quality and technical solutions obtained through these processes as a component of outcome-related quality.

Gaps occur when the expected average value is greater than the actual average value. Actually, the gap in numerical value can indicate some differences, but the difference is not accepted as a gap because according to the law of statistical differences in numerical values can be generated due to sample differences. Therefore, we must examine the probability of that gap in the case of population, (Mandal., 2018).

This study only uses 3 gaps: knowledge gap, standard gap, and delivery gap which are considered the basis of student satisfaction as a customer.

The knowledge gap is the gap between customer expectations and management perception/performance. This gap reveals that the manager/management perceives the customer>s expectations of the quality of service inaccurately. Some contributing factors include inaccurate information obtained from the research or market research and poor/ inaccurate ways to analyze the demand; improper and inaccurate interpretation of customer expectations information; lack of analysis of demand; lack of upward information from customer or customer contact staff to the management; and too many managerial levels that change information or impede what is passed from the employee to the manager. An example of different perceptions between customers and management is a food service manager (catering) who mistakenly thinks that their customers prioritize delivery timeliness and quantity of food portions, and yet the customers are more concerned with the various menu being served (Tjiptono \& Chandra, 2011).

Standards gap is a gap between performance/management>s perception of customer expectations and service quality specifications. This gap reveals the service quality or service specifications that are not consistent with management>s perception over customer expectations of quality. This is caused by the absence of standard operating procedures; mistakes in designing the planning or inadequate and inaccurate planning procedures; poor planning management; determination of unclear goals in the institution; less support and commitment from top management towards the quality of services planning; lack of resources; and the situation of excessive demand. For example, a bank manager asks his employees to serve customers <fast and accurately> without specifying the standard service times that can be categorized as fast and accurate (Tjiptono \& Chandra, 2011)

Delivery Gap is the gap between service quality specifications and service delivery which can be caused by the following reasons: quality specifications are too complex or inflexible and too rigid; employees do not agree to these specifications because they do not meet the requirements; specifications are not aligned with company culture; poor service operation management; insufficient internal marketing activities; existing systems and technologies do not facilitate performance according to requirements. Other causes of this gap are poorly trained employees, overworked employee workloads, and performance standards that can not be fulfilled by employees (unrealistic or too high). In addition, it may also be that employees are exposed to standards that conflict with one another. For example, hospital staff or nurses who have to take time to listen to patient complaints but at the same time they have to take care of every patient accurately and quickly (Tjiptono \& Chandra, 2011).

According to the regulation of the Ministry of State Apparatus Utilization (PERMENPAN) No. 3 of 2010, laboratories are academic support units in educational institutions in the form of closed or open spaces, permanent or mobile, systematically managed for testing, calibration, and/ or production on a limited scale by using equipment and materials based on certain scientific methods in the framework of the implementation of education, research, and/or community service (PKM). Types of laboratories according to PERMENPAN No. 3 of 2010 consist of four categories: the first type of laboratory is a basic science laboratory located in schools at the secondary education level or technical implementing unit that organizes education and/or training with supporting equipment facilities of the first and second categories, and the materials managed are in a general category to serve the educational activities of students. The second type of laboratory is a basic science laboratory in higher education at the level of preparation (first semester, second semester), or technical implementing unit that organizes education and/or training with supporting 
facilities of the first and second categories, and the materials managed are in a general category to serve student activities. The third type of laboratory is a scientific field laboratory in a program or major of study or a technical implementation unit (UPT) that organizes education and/or training of first, second, and third category equipment support facilities, and the material being managed is general and specific to serve educational activities and research of lecturers and students. The fourth type laboratory is an integrated laboratory at a university or faculty study center or a technical implementation unit (UPT) that organizes education and/or training with first, second, and third category equipment support facilities, and the material being managed is a general and specific category to provide services for research activities, community service (PKM), lecturers, and students.

\section{Research Methodology}

This research uses quantitative methods by distributing questionnaires offline and online (google form). The following is a series of procedures/steps for conducting research aimed at obtaining a systematically structured stage. (1) Preparation Stage is the stage of designing and making a questionnaire and determining the sample of questionnaire respondents. The questionnaire contained a statement of factors influencing the quality of laboratory in the engineering faculty based on grouping on the quality dimension. While the sample of respondents is determined based on the population of students of the Faculty of Engineering Unisba. (2) Data Collection Stage is the stage of distributing questionnaires to engineering faculty students, namely students of Industrial Engineering Study Program, students of Mining Engineering Study Program, and students of Urban and Regional Planning Engineering Study Program. Questionnaires distributed via Google aim to determine the level of quality of laboratory services at the Faculty of Engineering. (3) Data Testing Stage. Data testing is carried out in several stages, namely the calculation of the validity test and the reliability test. If the data tested does not meet the criteria, then the process is going back to phase 2 (data collecting). (4) The Processing Stage is carried out through the development method of SERVQUAL Gap Analysis Model. (5) Analysis and Conclusion Stage. After obtaining the results of the study, the process proceeds with the analysis and conclusion stages.
The stages are described in detail as follows: (1) Preparation Stage. This is the stage of designing and making the questionnaires about factors or dimensions and the quality of service in the laboratory of the engineering faculty as shown in table 1.

The next step is to determine the number of respondents or samples that represent the student population at the Faculty of Engineering. Quoting from Pratiwi and Chriswahyudi (2019); "Population is the area of generalization consisting of subjects having certain quantities and characteristics set by researchers to be studied and then drawn the conclusions of." The population used in this study are students of engineering faculty consisting of three study programs as shown in the Table 2.

Sample, according to Sugiyono (2007), is "Part of the total characteristics possessed by the population. Sample in this study determined based on the Slovin formula cited by Umar (2005) is as follows:

$$
n=\frac{N}{1+N e^{2}}
$$

Where:

$\mathrm{n}=$ The number of samples

$\mathrm{N}=$ The number of Population

$\mathrm{e}=$ Critical Value (the loose percentage of inaccuracy due to sampling errors that can still be tolerated or desired).

Based on calculations using the Slovin formula, a total sample of $n=328$ respondents from active students of the Faculty of Engineering with a population of $N=1796$ and a level of accuracy of 5\%. (2) Data Collection Stage. Distribution of offline and online (google form) questionnaires was conducted to 30 respondents in the Faculty of Engineering which include students of Regional and Urban Planning Engineering study program, Industrial Engineering study program, and Mining Engineering study program. (3) Data Testing Stage consists of two tests, namely the validity test and the reliability test. A validity test is a measured test showing that the measured variable is indeed the variable that will be observed by the researchers (Zulganef., 2006).

Based on the validity test, all attributes in the questionnaire were declared valid as shown in Table 3.

From the results of validity test shown in The Table 3, the value of $r$ table is smaller 
Table 1

Dimension of Quality and Questions

\begin{tabular}{|c|c|c|}
\hline No. & Dimension & Questions \\
\hline \multirow[t]{4}{*}{1.} & Tangible & $\begin{array}{l}\text { comfortable, clean, and spacious laboratory rooms in accordance with } \\
\text { laboratory standards }\end{array}$ \\
\hline & & $\begin{array}{l}\text { The quality and quantity of practicum tools are in accordance with the } \\
\text { needs of the practicum process }\end{array}$ \\
\hline & & Textbooks and modules in accordance with practicum material \\
\hline & & Complete and adequate supporting facilities for practicum \\
\hline \multirow[t]{3}{*}{2.} & Empathy & $\begin{array}{l}\text { Laboratory managers (Head of a laboratory, Laboratory Assistant, } \\
\text { Assistant) who give attention and prioritize practitioners }\end{array}$ \\
\hline & & The assistant has a concern for the practitioners \\
\hline & & $\begin{array}{l}\text { Practitioners are allowed to choose the practicum schedule according } \\
\text { to the schedule provided by the assistant at the time of practicum } \\
\text { registration in accordance with the "comfortable" time of the practitioner }\end{array}$ \\
\hline \multirow[t]{4}{*}{3.} & Responsiveness & The assistant responds to every complaint of practitioners \\
\hline & & The assistant provides quick and precise services \\
\hline & & The assistant accepts criticism and suggestions conveyed by practitioners \\
\hline & & $\begin{array}{l}\text { The assistant is willing to serve assistance in accordance with the specified } \\
\text { assistance time stated in the rules of practicum, as well as at the times } \\
\text { agreed by the assistant and the practitioners concerned }\end{array}$ \\
\hline \multirow[t]{4}{*}{4.} & Reliability & $\begin{array}{l}\text { Practicum starts and finishes according to the determined practicum } \\
\text { schedule }\end{array}$ \\
\hline & & The material presented is in accordance with the lecture material \\
\hline & & The assessment process is carried out objectively and transparently \\
\hline & & The assessment reports are well managed and documented \\
\hline \multirow[t]{5}{*}{5.} & Assurance & $\begin{array}{l}\text { Assistant provides accurate information about the stages and technical } \\
\text { implementation of the practicum }\end{array}$ \\
\hline & & $\begin{array}{l}\text { Assistants have the ability and competence to answer every question } \\
\text { from students who do the practicum }\end{array}$ \\
\hline & & $\begin{array}{l}\text { Assistant has knowledge and can be trusted in delivering practicum } \\
\text { material }\end{array}$ \\
\hline & & Assistant is being polite to the practitioner \\
\hline & & Assistant can create a conducive atmosphere for practicum activities \\
\hline
\end{tabular}

Table 2

Data on the Number of Active Students

\begin{tabular}{ll}
\hline Study Program & Number of Active Students \\
\hline Mining Engineering & 614 \\
Industrial Engineering & 666 \\
Regional and Urban Planning Engineering & 516 \\
\hline Total & 1796 \\
\hline
\end{tabular}

than $r$ count with a significant level of $5 \%(0.05)$. It means that a questionnaire consisting of 20 questions has met the standard and is declared valid. The next step is to carry out a reliability test to determine whether the instruments obtained have a good index if repeated testing is performed. A measurement instrument will be said to be reliable if the measurement produces consistency and accuracy. To facilitate accurate calculations, this study uses the SPSS version 16 application with the Cronbach
Alpha formula. A question on the questionnaire is considered reliable if the Cronbach Alpha value > 0.60 (Zulganef., 2006).

The Cronbach Alpha value of 0.946 shows that the 20 statements are quite reliable as shown in figure 2 . (4) The Processing Stage. The SERVQUAL Gap Analysis Model development method is used at this stage.

Quoting Deta Suara Pratiwi and Chriswahyudi (2019), the measurement of 
Table 3

The Validity Test Results

\begin{tabular}{cccc}
\hline Attribute & $\mathbf{r}$ table & r count & Description \\
\hline 1 & 0,1203 & 0,636 & Valid \\
2 & 0,1203 & 0,630 & Valid \\
3 & 0,1203 & 0,598 & Valid \\
4 & 0,1203 & 0,640 & Valid \\
5 & 0,1203 & 0,777 & Valid \\
6 & 0,1203 & 0,783 & Valid \\
7 & 0,1203 & 0,685 & Valid \\
8 & 0,1203 & 0,824 & Valid \\
9 & 0,1203 & 0,817 & Valid \\
10 & 0,1203 & 0,798 & Valid \\
11 & 0,1203 & 0,763 & Valid \\
12 & 0,1203 & 0,713 & Valid \\
13 & 0,1203 & 0,641 & Valid \\
14 & 0,1203 & 0,713 & Valid \\
15 & 0,1203 & 0,773 & Valid \\
16 & 0,1203 & 0,755 & Valid \\
17 & 0,1203 & 0,735 & Valid \\
18 & 0,1203 & 0,814 & Valid \\
19 & 0,1203 & 0,803 & Valid \\
20 & 0,1203 & 0,690 & Valid \\
\hline
\end{tabular}

\section{Reliability}

\section{Scale: ALL VARIABLES}

Case Processing Summary

\begin{tabular}{llr|r}
\multicolumn{1}{c}{} & \multicolumn{2}{c}{$\mathrm{N}$} & \multicolumn{2}{c}{$\%$} \\
\hline \multirow{3}{*}{ Cases } & Valid $^{*}$ & 262 & 99,2 \\
\cline { 2 - 4 } & Excluded $^{\text {a }}$ & 2 &, 8 \\
\cline { 2 - 4 } & Total $^{2}$ & 264 & 100,0 \\
\hline
\end{tabular}

a. Listwise deletion based on all variables in the procedure.

\section{Reliability Statistics}

Cronbach's

Alpha

94

20

Figure 2. The Results of Reliability Test

service quality in the SERVQUAL method is based on a multi-item scale designed to measure customer expectations and perceptions and gap between the two on five main dimensions of service quality (reliability, responsiveness, assurance, empathy, and physical evidence). The five main dimensions are broken down into each of the detailed attributes for the expectation and perception variables arranged in statements based on a Likert scale from (not very good) to 5 (very good). SERVQUAL scores for each pair of statements for each customer can be calculated based on the following formula (Zeithaml et al, 2008).

At this stage, according to Tjiptono \& Chandra (2011), the formula to get SERVQUAL scores is: Servqual score $=$ Perception score Expectation score

Data obtained through the SERVQUAL instrument can be used to calculate service quality gap scores at various levels in detail. (5) Analysis and Conclusion Stage. After processing the data and get the results, the next step is to study and analyze the research results.

\section{Results and Discussion}

Table 4 is the average calculation of actual values and expected values as well as the gap values in the tangible dimensions. The largest gap value is 'a laboratory room that is comfortable, clean, and spacious in accordance with laboratory standards' with a value of -1.38 . The laboratory room has the biggest gap value because it is the practitioners feel less comfortable with the condition of laboratory right now which has 
Table 4
The Calculation of Tangible Dimension Gap Value

\begin{tabular}{lllll}
\hline No. Statement & \multicolumn{2}{l}{ Perception } & Expectation & GAP \\
\cline { 3 - 3 } & & Average & Average & \\
\hline 1 & $\begin{array}{l}\text { Comfortable, clean, and spacious laboratory rooms in } 3,32 \\
\text { accordance with laboratory standards }\end{array}$ & 4,70 & $-1,38$ \\
2 & $\begin{array}{l}\text { The quality and quantity of practicum tools are in } \\
\text { accordance with the needs of the practicum process }\end{array}$ & 4,43 & $-0,94$ \\
3 & $\begin{array}{l}\text { Textbooks and modules in accordance with practicum } \\
\text { material }\end{array}$ & 4,14 & $-0,53$ \\
4 & Complete and adequate supporting facilities for practicum 3,36 & 4,46 & $-1,10$ \\
\hline
\end{tabular}

Table 5

The Calculation of Empathy Dimension Gap Value

\begin{tabular}{|c|c|c|c|c|}
\hline \multirow[t]{2}{*}{ No. } & \multirow[t]{2}{*}{ Statement } & \multirow{2}{*}{$\begin{array}{l}\text { Perception } \\
\text { Average }\end{array}$} & \multirow{2}{*}{$\begin{array}{l}\text { Expectation } \\
\text { Average }\end{array}$} & \multirow[t]{2}{*}{ GAP } \\
\hline & & & & \\
\hline 5 & $\begin{array}{l}\text { Laboratory managers who give attention and prioritize } \\
\text { the practitioners }\end{array}$ & 3,87 & 4,76 & $-0,89$ \\
\hline 6 & The assistant has a concern for the practitioners & 3,87 & 4,70 & $-0,83$ \\
\hline 7 & $\begin{array}{l}\text { Practitioners are allowed to choose the practicum schedule } \\
\text { according to the schedule provided by the assistant at } \\
\text { the time of practicum registration in accordance with the } \\
\text { "comfortable" time of the practitioner }\end{array}$ & 4,14 & 4,89 & $-0,75$ \\
\hline
\end{tabular}

a narrow practicum room. Laboratory needs repairment on the hygiene standards to be used comfortably.

Table 5 is a calculation of the average of actual value and expectation value and also the gap value in the dimensions of empathy. The biggest gap value is 'the laboratory managers (head of laboratory, laboratory assistant, assistant) who give attention and prioritize practitioners' with a value of -0.89 . It has the biggest score because the practitioner feels less satisfied with the services provided by laboratory management from the head of the laboratory, laboratory assistant, and assistants. Based on the results, the laboratory assistant and assistants must prioritize the practitioners.

Table 6 is a calculation of the average of actual value and expectation value and also the gap value in the dimensions of responsiveness. The biggest gap value is 'assistant accepts criticism and suggestions conveyed by practitioners' with the value of $-0,71$. It has the biggest value because practitioners think that the assistant can't accept criticism and suggestions from them. Based on the results of the gap, the assistant needs professional attitude in doing his/her job.

Table 7 is a calculation of the average of actual value and expectation value and also the gap value in the dimensions of reliability. The biggest gap value is 'The assessment process is carried out objectively and transparently' with the value of $-0,79$. It has the biggest value because practitioners think that the evaluation process is not carried out objectively and transparently. Based on the results of the gap, the assistant needs a professional attitude in doing his/her job.

Table 8 is a calculation of the average of actual value and expectation value and also the gap value in the dimensions of assurance. The biggest gap value is 'assistant is being polite to the practitioners' with the value of $-0,67$. It has the biggest value because practitioners think that the assistant should be polite to them. Based on the results of the gap, an assistant should know his/her role well.

Table 9 is a recapitulation of the calculation of the average value of actual and expectations and the gap value in the dimensions of quality (tangible, empathy, responsiveness, reliability, and assurance). Reliability has the biggest quality dimension satisfaction value of 4,035 which means that the practitioners assess the practicum schedule is appropriate, the material presented is in accordance with the lecture material, the assessment process is carried out objectively and transparently, and the 
NUGRAHA. et al. A Gap Model Analysis of Laboratory Service Quality at Engineering Faculty ...

Table 6

The Calculation of Responsiveness Dimension Gap Value

\begin{tabular}{lllll}
\hline No. Statement & \multicolumn{3}{l}{ Perception } & Expectation \\
\cline { 3 - 4 } & & Average & Average & \\
\hline 8 & Assistant responds to every complaint of practitioners & 3,92 & 4,60 & $-0,68$ \\
9 & Assistant provides quick and precise services & 3,86 & 4,55 & $-0,69$ \\
10 & $\begin{array}{l}\text { The assistant accepts criticism and suggestions conveyed } \\
\text { by practitioners }\end{array}$ & 3,89 & 4,60 & $-0,71$ \\
11 & $\begin{array}{l}\text { The assistant is willing to serve assistance in accordance } \\
\text { with the specified assistance time stated in the rules of } \\
\text { practicum, as well as at the times agreed by the assistant } \\
\text { and the practitioners concerned }\end{array}$ & 4,77 & $-0,66$ \\
\hline
\end{tabular}

Table 7

The Calculation of Reliability Dimension Gap Value

\begin{tabular}{llll}
\hline No. Statement & $\begin{array}{c}\text { Perception } \\
\text { Average }\end{array}$ & $\begin{array}{l}\text { Expectation GAP } \\
\text { Average }\end{array}$ \\
\hline 12 & $\begin{array}{l}\text { Practicum starts and finishes according to the determined } \\
\text { practicum schedule }\end{array}$ & 4,78 & $-0,75$ \\
13 & $\begin{array}{l}\text { The material presented is in accordance with the lecture } \\
\text { material }\end{array}$ & 4,11 & $-0,69$ \\
14 & $\begin{array}{l}\text { The assessment process is carried out objectively and 3,97 } \\
\text { transparently }\end{array}$ & 4,76 & $-0,79$ \\
15 & The assessment reports are well managed and documented 4,03 & 4,68 & $-0,65$ \\
\hline
\end{tabular}

assessment documentation is well managed. Empathy dimension has the biggest value of expectation of 4,780 which means that practitioners demand the concern/attention from the laboratory managers, assistant; and practitioners are allowed to choose practicum schedule.

The tangible dimension has the biggest gap value of $-1,02$ because practitioners put their expectations high relating to the tangible, but the reality shows different results. They are not satisfied, particularly about (1). Comfortable, clean, and spacious laboratory rooms in accordance with laboratory standards; (2). Complete and adequate supporting facilities for practicum; (3) The quality and quantity of practicum tools are in accordance with the needs of the practicum process.

Based on the above description it can be seen that the average value of the dimensions of service quality (tangible, empathy, responsiveness, reliability, assurance) as a whole is expected to be 4,678 ; while the actual average value is 3,913 . It means there is a gap since the average of expectation value is greater than the actual value. It is only gap 1, 2, and 3 will be discussed in this study because they underlie student satisfaction. The following is the detail of each gap. Gap 1 is the gap between customer (student) expectations and perceptions towards institutional management (laboratory managers). Based on the findings, the gap values for all quality dimensions are as follows: tangible with the value of -1.02 , empathy value of -0.77 , responsiveness value of -0.69 , reliability value of -0.72 , and assurance value of -0.64 . It can be seen that all dimensions of service quality are still negative, meaning that students as customers are still not satisfied with the services provided by the laboratory manager. Gap 2 is the difference between the perception of management (laboratory manager) towards consumer (student) expectations and service quality specifications. Based on the findings, the overall quality dimension is still negative which occurs due to inadequate interpretation of laboratory management perceptions to the expectations of students as customers in the form of service quality benchmarks. For the dimensions of service quality, tangible has the highest gap value so that the attributes in this dimension should receive attention and priority compared to other quality dimensions. Solutions that can be offered for tangible gaps are (1) laboratory managers should conduct research or gather formal and informal information about students' needs and expectations, (2) head of laboratories 
Table 8

The Calculation of Assurance Dimension Gap Value

\begin{tabular}{|c|c|c|c|c|}
\hline No. & Statement & $\begin{array}{l}\text { Perception } \\
\text { Average }\end{array}$ & $\begin{array}{l}\text { Expectation } \\
\text { Average }\end{array}$ & GAP \\
\hline 16 & $\begin{array}{l}\text { Assistant provides accurate information about the stages and } \\
\text { technical implementation of the practicum }\end{array}$ & 4,09 & 4,74 & $-0,65$ \\
\hline 17 & $\begin{array}{l}\text { Assistants have the ability and competence to answer every } \\
\text { question from students who do the practicum }\end{array}$ & 3,92 & 4,56 & $-0,64$ \\
\hline 18 & $\begin{array}{l}\text { Assistant has the knowledge and can be trusted in delivering } \\
\text { practicum material }\end{array}$ & 4,02 & 4,66 & $-0,65$ \\
\hline 19 & Assistant is being polite to the practitioner & 4,01 & 4,68 & $-0,67$ \\
\hline 20 & $\begin{array}{l}\text { Assistant can create a conducive atmosphere for practicum } \\
\text { activities }\end{array}$ & 4,10 & 4,68 & $-0,58$ \\
\hline
\end{tabular}

Table 9

Recapitulation of Quality Dimension Gap Calculation

\begin{tabular}{lllll}
\hline No. Statement & \multicolumn{3}{c}{ Perception Expectation } & GAP \\
\cline { 3 - 5 } & & 3 Average & Average & \\
\hline 1 & Tangible & 3,545 & 4,565 & $-1,02$ \\
2 & Empathy & 4,010 & 4,780 & $-0,77$ \\
3 & Responsiveness & 3,945 & 4,630 & $-0,69$ \\
4 & Reliability & 4,035 & 4,755 & $-0,72$ \\
5 & Assurance & 4,028 & 4,664 & $-0,64$ \\
\hline
\end{tabular}

should looking for, stimulating and facilitating the flow of information from laboratory assistants at lower levels of management such as assistants laboratory, and others. Other things noteworthy are (1) The head of the laboratory shows a continuing commitment to quality based on the perspective of students as customers, (2) Involve laboratory assistants and other assistants in establishing, communicating, and standardizing customeroriented laboratories in laboratory work units. (3) To equip laboratory assistants and other assistants with the skills needed through training programs. Gap 3 is the gap between service quality specifications and service delivery. Based on the research findings, knowing the human resources (HR) of laboratory managers are less skilled to meet the service quality standards that have been set, it is necessary to prioritize improvements as follows: (1) A clear and detailed description of the role of each laboratory assistant and other assistants, (2) Laboratory assistants and other assistants understand the contribution of their work to student satisfaction, (3) Select laboratory assistants based on the expertise or abilities and skills needed so that they can do their jobs properly and correctly, (4) Build a work team as such so that laboratory assistants and other assistants can work well together.

\section{Conclusions}

Based on the results of research and observation, the average value of the dimensions of service quality as a whole is expected to be 4,678; while the actual average value is 3,913 which means there is a gap since the average of expectation value is greater than the actual value. It can be concluded that the perceived value of the overall quality dimension which includes tangible, empathy, responsiveness, reliability, and assurance is still smaller than the expected value.

Students are unsatisfied because their expectations can not be fulfilled yet and there are still gaps between students and the laboratory manager in the faculty of engineering. Thus, it is recommended for laboratory managers to make improvements, especially for dimensions that have a large gap, for example, by providing comfortable, clean, and spacious laboratory rooms in accordance with laboratory standard; complete and adequate supporting facilities for practicum; the quality and quantity of practicum tools are in accordance with the needs of practicum process. 
NUGRAHA. et al. A Gap Model Analysis of Laboratory Service Quality at Engineering Faculty ...

\section{Acknowledgment}

The researchers would like to thank the LPPM UNISBA for funding this research through the Main Lecturer Research (PDU) scheme in the academic year of 2018 - 2019.

\section{References}

Ahmadi, Dadi, \& Yanuarti, E. (2020). Reflective Writing: Students' Diaries to Improve the Teaching and Learning Process. 521-524. https://doi.org/10.2991/ assehr.k.200225.113

Afridi, S.A., Khattak, A., \& Khan, A., (2016). Measurement of service quality gap in the selected private universities/institutes of peshawar using SERVQUAL model. City University Research Journal, 6 (1)

Alijanzadeh, M., Fattahi, H., Veisi, F., Alizadeh, B., Khedmatgozar, Z. and Gholami, S., (2018). Assessment of Educational Service Quality Gap: The Students' Perspectives. Educational Research in Medical Sciences, 7(1).

Amin, Solekhul. (2017). Strategi Peningkatan Kualitas layanan Akademik Pada Perguruan Tinggi. Jurnal Madaniyah, Volume 7 Nomor 2 Edisi Agustus 2017.

Al-Alak, B. A., \& Alnaser, A. S. M. (2012). Assessing the relationship between higher education service quality dimensions and student satisfaction. Australian Journal of Basic and Applied Sciences, 6(1), 156164.

Amelia, L., Hidayanto, A. N., \& Hapsari, I. C. (2011). Analysis of IS/IT service quality in the higher education with SERVQUAL: A case study of STMIK MDP Palembang. The 2 nd International Research Symposium in Service Management, July 26-30, 2011, Yogyakarta, Indonesia.

Abu Hasan, H. F., Ilias, A., Abd Rahman, R., \& Abd Razak, M. Z. (2008). Service quality and student satisfaction: A case study at private higher education institutions. International Business Research, 1(3), 163-175.

Fitzsimmons, James A and Mona J. Fitzsimmons. (2011). Service Management: Operation, Strategy, Information Technology 7th edition. The McGraw Hill. International Editions.

Gagandeep Banga, Babita Kumar dan Kranti Kishore Maurya. (2013). Service Quality Assessment of Food-Based Superstores. Indian Management Studies Journal 17 1-16.

Gaspersz, Vincent, (2012), All In One:
Production and Inventory Management, Edisi 8, Bogor

Hoe, T. C. (2004). Measuring student perception of Service Quality in higher education. Dissertation, DBA program of the University of South Australia.

Umar, Husein., (2005), Metode Penelitian Untuk Tesis Dan Bisnis, Jakarta: Grafindo Persada.

Khodayari, F., \& Khodayari, B. (2011). Service quality in higher education. Interdisciplinary Journal of Research in Business, 1(9), 38-46.

Legčević, J. (2009). Quality gap of educational services in viewpoints of students. Ekonoska Misao Praksa DBK. GOD, 18 (2), 279-298.

McColl, R., Callaghan, B., \& Palmer, A. (1998). Services Marketing: a Managerial Perspective. Sydney: McGraw-Hill.

Mandal, Kaushik, and Hemant Gupta. (2018) "Service Quality Gap Measurement in Pharmaceutical Educational Institutes: An Empirical Analysis for Model Development." Indian Journal of Pharmaceutical Education and Research 52.3 (2018): 351-62.

Mohamad Yusof, A.R., Hassan, Z., Abdul Rah man, S., \& Ghouri, A. M. (2012). Educational service quality at public higher educational institutions: A proposed framework and importance of the subdimensions. International Journal of Economics Business and Management Studies, 1(2), 36-49.

Nugraha, Nasution, A., \& Amaranti, R., (2015). Pengembangan Model Services Quality untuk Peningkatan Kualitas Layanan Akademik Internal di Perguruan Tinggi. Jurnal Ethos, Volume 2, Nomor 2, Hal $191-198$

Parasuraman, A., Zeithaml, V. A., \& Berry, L. (1985) "A conceptual model of service quality and its implications for further research", Journal of Marketing, vol. 49 (Fall), pp. 41-50.

Parasuraman, A., Zeithaml, V. A., \& Berry, L., (1988). SERVQUAL: a multiple-item scale for measuring consumer perceptions of quality. Journal of Retailing, 64(1), 12-40.

Peraturan Menteri Negara Pendayagunaan Aparatur Negara (PERMENPAN) Nomor 3 Tahun 2010 tentang Jabatan Fungsional Pranata Laboratorium Pendidikan

Pratiwi, Deta dan Chriswahyudi. (2019). Analisis Pengaruh Kualitas Pelayanan Jasa Kesehatan Terhadap Kepuasan Pasien BPJS di Klinik DK Bintaro dengan Metode Kano, SERVQUAL dan Gap Analysis. 
Seminar Nasional Teknologi Fakultas Teknik Universitas Krisnadwipayana, Jakarta.

Rapert, M. I., \& Wren, B. M. (1998). Reconsidering organizational structure: A dual perspective of frameworks and processes. Journal of Managerial Issues, $10(3), 287-302$.

Sugiyono (2007). Metode Penelitian Kuantitatif Kualitatif dan R\&D. Bandung: Alfabeta.

Taylor, S. A., and Baker, T.L. (1994). An assessment of the relationship between service quality and customer satisfaction in the formation of consumers' purchase intentions", Journal of Retailing, Vol. 70, No. 2, pp. 163-178.

Tjiptono, F dan Chandra, G.; (2011). Service, Quality, and Satisfaction. Edisi ke-3. Yogyakarta: Andi.

Yulianti, Y., (2017. Analisis Kualitas Pelayanan Pendidikan dengan Menggunakan Gap Analysis dan Importance Performance Analysis (IPA) pada Program Studi Pendidikan Ekonomi Fakultas Ekonomi
UNY. Jurnal Pendidikan ekonomi, Volume 6, Nomor 2, 2017.

Yousapronpaiboon, K.,(2014). SERVQUAL: Measuring higher education service quality in Thailand, Procedia - Social and Behavioral Sciences 116 ( 2014) 1088 $-1095$

Zeshan, A., Afridi, T., \& Khan, S. M. (2010). Assessing service quality in business schools: implications for improvement. The 3rd International Conference on Assessing Quality in Higher Education, December 6-8, 2010, Lahore - Pakistan, 220-232.

Zeithaml, Valarie A., Bitner, Mary Jo., and Gremler, Dwayne D,, (2008) Service Marketing: Integrated Customer Focus Across the Firm, McGraw - Hill Education (UK) Limited.

Zulganef (2006) The existence of overall satisfaction in service customer relationships, Gadjah Mada International Journal of Business, Vol. 8, No. 3, pp. 301-321. 